\title{
Tantangan Teologi Agama-agama: Suatu Diskursus Model
}

\section{Hasahatan Huatahaean}

Sekolah Tinggi Teologi Sumatera Utara, Medan, Sumatera Utara

hasea2014@gmail.com

\begin{tabular}{|c|c|}
\hline $\begin{array}{l}\text { Article History } \\
\text { Submitted: } \\
\text { 23 January } 2020 \\
\text { Revised: } \\
01 \text { April } 2020 \\
\text { Accepted: } \\
\text { 05 May } 2020\end{array}$ & $\begin{array}{l}\text { Abstract: Live side by side between religions is no longer a choice of life, } \\
\text { especially in Indonesia. Because Indonesian society is formed from various } \\
\text { religions and tribes or sub-tribes. Therefore, the effort to find a format and } \\
\text { order to live side by side in getting along well and harmony is a relevant topic } \\
\text { of all time. In this paper, the pattern of life in diversity is traced to the time of } \\
\text { the first human life on earth through the narrative of the Scriptures in } \\
\text { Christianity, the Bible. With the help of searching for cognate libraries, this }\end{array}$ \\
\hline $\begin{array}{l}\text { Keywords: } \\
\text { diversity; } \\
\text { harmony; } \\
\text { religion; } \\
\text { theology of } \\
\text { religions }\end{array}$ & $\begin{array}{l}\text { paper presents proposals that are simple and easy to understand for each } \\
\text { adherent of the religion. Various data collected were then processed using the } \\
\text { heuristic inquiry theory approach while the data from the scriptures were } \\
\text { explored with a hermeneutic pattern. The tripolar typology that is considered to } \\
\text { be the first or pioneering pattern in the theology of religions is now gaining a } \\
\text { new partner in realizing life between religious communities towards harmony. }\end{array}$ \\
\hline $\begin{array}{l}\text { agama; } \\
\text { harmonis; } \\
\text { keberagaman; } \\
\text { teologi agama- } \\
\text { agama }\end{array}$ & $\begin{array}{l}\text { Abstrak: Hidup berdampingan antar pemeluk agama tidak lagi menjadi pilihan } \\
\text { hidup, apalagi di Indonesia. Sebab masyarakat Indonesia terbentuk dari } \\
\text { berbagai agama dan suku atau sub-suku. Karena itu pula upaya mencari format } \\
\text { dan tatanan hidup berdampingan dengan rukun dan harmonis menjadi topik } \\
\text { yang relevan sepanjang masa. Dalam tulisan ini, pola kehidupan dalam } \\
\text { keberagaman ditelusuri hingga masa-masa kehidapan pertama manusia di bumi } \\
\text { melalui narasi Kitab Suci dalam kekristenan yaitu Alkitab. Dengan bantuan } \\
\text { penelusuran pustaka serumpun, tulisan ini menyajikan usulan yang sederhana } \\
\text { dan mudah untuk dimengerti oleh masing-masing pemeluk agama. Berbagai } \\
\text { data yang berhasil dihimpun kemudian diolah dengan pendekatan teori heuristic } \\
\text { inquiry sedangkan data dari kitab suci didalami dengan pola hermeneutik. } \\
\text { Kerangkeng tipologi tripolar yang dianggap menjadi pola pertama atau perintis } \\
\text { dalam teologi agama-agama kini memperoleh mitra baru dalam mewujudkan } \\
\text { kehidupan antar umat beragama menuju keharmonisan. }\end{array}$ \\
\hline
\end{tabular}

\section{Pendahuluan}

Veli-Mati Karkkainen pada tahun 2012 pernah berceramah terkait pluralisme agama, berangkat dari penjelasan pengajaran Tritunggal, mengusulkan agar tidak mengurangi kebenaran ajaran yang terkandung pada dasar iman Kristen tentang tritunggal kepada umat kristiani ketika berhadapan dengan umat dari agama lain. Tak lama setelah itu terbit buku Karkkainen berjudul "Tritunggal dan Pluralisme Agama". ${ }^{1}$ Karkkainen khususnya berangkat dari topik yang paling sensitif untuk dibicarakan dalam ranah Teologi Agama, yaitu pengajaran tentang Tritunggal. Topik ini disebut sensitif karena perbedaan pemahaman tentang tritunggal banyak ditemukan diantara teolog Kristen. Dalam buku itu Karkkainen menyatakan

${ }^{1}$ Veli-Mati Karkkainen, Tritunggal Dan Pluralisme Agama (Jakarta: BPK Gunung Mulia, 2013). 
bahwa bidang teologi agama-agama ini masih baru dan masih mencari kanon. ${ }^{2}$ Teologi agama-agama dalam hal ini bisa ditemukan di berbagai negara atau komunitas. Misalnya ketika era kitab Kejadian dan di sekitar Mesir dengan ditemukannya "banyak hukum-hukum kasus Israel serupa dengan peraturan dari bangsa-bangsa lain. ${ }^{3}$ Juga ketika kehadiran Yesus yang menghadapi banyak agama-agama dan berdialog terbuka pada masa itu.

Terkait dialog antar agama, Glasaer menjelaskan hal tersebut telah terjadi di banyak zaman, dalam berbagai era kepemimpinan berbagai bangsa sejak masa orang Israel di Mesir hingga perkembangan agama-agama kemudian di Asia maupun Eropa. ${ }^{4}$ Dalam Perjanjian Lama dapat ditemukan narasi semangat teologi agama-agama saat orang-orang keturunan Yakub berada di perjalanan menuju Kanaan. Meski dapat dipahami kala itu pola yang dipergunakan cenderung saling serang dan menutup diri terhadap perbedaan. Tidak jarang Alkitab menuliskan pertentangan dan peperangan dari umat pilihan Allah ketika bersinggungan dengan kelompok masyarakat lain yang berbeda pemahaman/teologi. Umat Allah yang dalam narasi Alkitab dituliskan dengan keturunan Abraham, Ishak dan Yakub, memiliki pemahaman theism (ketuhanan-keilahian), sedangkan orang-orang yang ada di sekitar Kanaan, menganut pemahaman kepercayaan kepada banyak ilah, allah atau sesembahan. Misalnya, menurut John Drane, sejumlah tempat ibadah di Hebron, Bersyeba dan Mizpa (Kej.13:18; 18:1-15; 26:2326; 31:43-55) kemungkinan adalah tempat ibadah orang Kanaan sebelum Israel tiba di sana, sebelum patriarch Ibrani tiba di tempat itu..$^{5}$ Alasannya, karena para patriarch juga digambarkan membangun pusat ibadah yang baru.

Di Mesir pun anak-anak Ishak diperhadapkan dengan sikap dan spirit teologi agamaagama. Bagaimana kerumitan satu rumah tangga harus menghormati dewa yang disembah oleh raja, pembesar, namun di rumah masing-masing mereka juga harus menghadirkan dewa, patung, sesembahan secara mandiri. ${ }^{6}$ Interaksi interpersonal juga mau tak mau diwarnai ego ilah masing-masing sebab masing-masing keluarga berangkat dari dewa, patung, sesembahan yang belum tentu sama. Hal yang sama dipertanyakan oleh Tanzil, dengan keberagaman atau perbedaan ini, mungkinkah seseorang untuk memulai pengamatan dengan sudut yang netral murni dan bebas dari sudut partikular? ${ }^{7}$

Demikian pula pasca-kenaikkan Yesus (Kis.1:9-11), para Rasul dihadapkan dengan berbagai agama yang berbeda. Ada yang berhasil berdampingan, namun ada pula yang tertindas karena kekalahan spiritual serta kolonialisme, yakni penjajahan Romawi. Terutama Kekristenan yang mengarah ke Asia, menghadapi pelbagai macam agama dan ratusan agama suku, yang kerapkali akur-harmonis, namun tak jarang berbenturan. Hal ini menjadi lebih ru-mit sebab tidak banyak literatur yang tertarik untuk menuliskannya, meski di lapangan penga-nut berbagai agama di dunia mempraktikkannya. Ada yang berhasil (damai, berdampingan, har-

\footnotetext{
${ }^{2}$ Ibid.

${ }^{3}$ John Drane, Memahami Perjanjian Lama III, ed. Barnabas Ludji, Ketiga. (Jakarta: Scripture Union Indonesia, 2017), 38.

${ }^{4}$ Ida Glasaer, Alkitab Dan Kepercayaan Lain, ed. Paul S. Hidayat (Jakarta: Waskita Publishing, 2012), 47.

${ }^{5}$ Drane, Memahami Perjanjian Lama III.

${ }^{6}$ Glasaer, Alkitab Dan Kepercayaan Lain.

${ }^{7}$ Vincent Tanzil, "Dalam Allah Trinitas Dialog Antar Iman Hidup, Bergerak, Dan Ada," Amanat Agung 9 (2) (2013): 225.
} 
monis) dan tak jarang pula yang gagal (berbenturan, kontra literatur maupun fisik), baik di dunia maya dan di dunia nyata. Keharmonisan dan kerukunan dalam kehidupan antar agama menjadi salah satu tujuan agama-agama itu. Sedangkan teologi agama-agama adalah salah satu alat, media yang pada khususnya dipakai dalam teologi Kristen untuk menemukan pola yang tepat guna mencapai salah satu tujuan tersebut. Tulisan ini bertujuan untuk mengambil bagian dalam jalan mencapainya kehidupan yang harmonis tersebut.

Dari sisi sosio-religius di Indonesia, Bambang Budijanto menyatakan, "Nasionalisme agama telah memicu intensitas konflik antar agama sejak akhir dekade 80-an." ${ }^{\circ}$ Daniel Nuhamara, dalam prawacana untuk buku Djoys Anneke Rantung, juga menyatakan hal yang cukup mengkhawatirkan, yakni dalam masyarakat majemuk seperti Indonesia, perbedaanperbedaan karena suku, agama dan kelas rentan dijadikan alasan untuk konflik dan tak jarang disertai dengan kekerasan. ${ }^{9}$ Dalam sejarah orde baru di Indonesia, Theodorus Sibarani menuliskan bahwa teologi Kristen pernah mengambil peran dan porsi tersendiri kala itu. ${ }^{10}$ Dengan mengutip pemaparan Drewes dan Julianus Mojau, Sibarani menyebut bahwa teologi di Indonesia menghasilkan suatu paradigma yang disebut dengan paradigma rangkap. ${ }^{11}$ Di satu sisi teologi diperhadapkan oleh pergumulan akan firman, namun di sisi lain pergumulan masyarakat yang sedang memulai pembangunan nasional. Alih-alih memainkan peran yang ideal, teologi tanpa disadari telah menjadi ideologi atau alat pembenaran kegiatan pembangunan yang dalam prosesnya telah melahirkan sikap-sikap negatif seperti korupsi dan ketidakadilan.

Terkait studi terhadap teologi agama-agama, telah dilakukan beberapa penulis terdahulu. Pembatasan sengaja dilakukan untuk memberikan lingkup yang terukur dalam penelusuran pustaka tersebut. Yakni ditinjau dari penulis Indonesia, karena rasa dan kekhasan tulisan ini tampak ke-indonesiaannya. Tulisan dari Hans Abdiel Harmakaputra, mencoba memberikan celah baru dalam kebuntuan teologi agama-agama klasik sejak tipologi tripolar ada; usul yang mencuat adalah dialog antar iman. ${ }^{12}$ Teologi harus terus-menerus bergerak saling mempengaruhi. Tentu tak lupa menelusuri tulisan terkini dari Joas Adiprasetya ${ }^{13}$ dan karya Edi S Ginting ${ }^{14}$, yang juga memberikan warna dalam pemaknaan teologi Kristen. Serupa dengan Karkkainen, Joas menjadikan doktrin tritunggal untuk menjabarkan arah dan praksis teologi agama-agama. Ketertarikan kedua penulis ini adalah berangkat dari kebangkitan doktrin trinitas, dan-bagi Joas-studi teologi agama-agama digabungkan dalam hasrat agar lebih koheren dan komprehensif. ${ }^{15}$ Mendiskusikan teologi agama-agama dapat diawali dengan memperbincangkan Tritunggal dengan tetap memberikan penghargaan kepada pengertian

\footnotetext{
${ }^{8}$ Bambang Budijanto, "Spiritualitas Generasi Muda Dan Gereja," in Dinamika Spiritualitas Generasi Muda Kristen Indonesia, ed. Budijanto (Jakarta: Bilangan Research Center, 2018), 30.

${ }^{9}$ Djoys Anneke Rantung, Resolusi Konflik Dalam Organisasi (Jakarta: BPK Gunung Mulia, 2017), ix.

${ }^{10}$ Theodorus B Sibarani, "Berteologi Dalam Pembangunan Sosial Di Indonesia," in Dari Disabilitas Ke Penebusan: Potret Pemikiran Teolog-Teolog Muda Indonesia, ed. Samuel Septino Saragih (Jakarta: Asosiasi Teolog Indonesia dan BPK Gunung Mulia, 2016), 167-188.

${ }^{11}$ Ibid.

${ }^{12}$ Hans Abdiel Harmakaputra, Melepas Bingkai (Jakarta: Grafika Kreasindo, 2014). 118

${ }^{13}$ Joas Adiprasetya, An Imaginative Glimpse; Trinitas Dan Agama-Agama (Jakarta: BPK Gunung Mulia, 2018).

${ }^{14}$ Edi S Ginting, "Theologia Religionum (Teologi Agama-Agama)," in Teologi-Teologi Kontemporer, ed. Jan S Aritonang (Jakarta: BPK Gunung Mulia, 2018), 184-201.

15 Adiprasetya, An Imaginative Glimpse; Trinitas Dan Agama-Agama.
} 
masing-masing agama. Sedangkan Edi S Ginting pada bagian akhir topik Teologi Agamaagama mendandaskan perlunya kedewasaan dalam mewujudkan kerukunan antar umat beragama. Dengan mengutip ide Raymond Plant, bahwa teologi pluralis ini akan lebih dapat diterima pada masyarakat liberal dan plural. ${ }^{16}$

Thio Christian Sulistio berkeyakinan bahwa doktrin-doktrin seperti penyataan umum Allah, kerusakan total manusia dan anugerah umum Allah yang berdasarkan pengajaran Alkitab dengan benar menolong seseorang untuk memahami keberadaan agama-agama lain secara teologis. ${ }^{17}$ Sebab itu dari masing-masing doktrin tersebut mempunyai kontribusi tersendiri bagi terwujudnya kehamonisan dari sisi teologi agama-agama. Misalnya dari pemahaman doktrin anugerah umum yang alkitabiah akan membuat adanya gradiasi intensitas dan derajat dari penindasan manusia terhadap kebenaran; tidak semua orang menindas kebenaran dengan intensitas dan derajat yang sama. ${ }^{18}$ Konsekuensi dari konsep ini yakni bisa saja ada agama yang dekat dengan Kekristenan, juga sebaliknya ada yang bertentangan. Dari buku dan jurnal yang ada, tentu tidak lepas dari pantauan dalam tulisan ini yaitu pioneer tipologi tripolar dari Alan Race yang menjadi titik awal literasi teologi agama-agama para teolog di dunia. ${ }^{19}$ Tipologi tripolar adalah tiga pendekatan teologi agama-agama dalam khazanah Kristen bagaimana membangun relasi dengan agama-agama lain. Tiga pendekatan itu yang akan dijelaskan kemudian pada tulisan ini; eksklusivisme, inklusivisme dan pluralisme. Dengan bantuan pustaka tersebut, berdaya dorong untuk menuntun penulis untuk mencari jalan lain menuju teologi agama-agama yang harmonis dan tampak adil bagi semua pemeluk agama-agama.

\section{Metode Penelitian}

Tulisan ini dimaksud untuk memaparkan pandangan yang ada tentang Teologi Agama-agama, serta bagaimana praksis yang ada. Dengan mengandalkan literatur yang telah ada, penelitian ini mencoba merunut beberapa istilah yang tak asing (misalnya tipologi tripolar) serta beberapa hambatan terwujudnya teologi agama-agama yang harmonis. Metode yang digunakan dalam kajian ini adalah metode analisis terhadap isi. Analisis terhadap isi digunakan untuk memahami 'apa, kepada siapa, dan bagaimana' dari suatu proses komunikasi. ${ }^{20}$ Kajian tulisan ini merupakan kajian pustaka, dengan objek literatur yang terkait dengan teologi agamaagama yang beredar saat ini, berangkat dari tipologi tripolar. Setelah sepintas mengungkap fakta itu, maka penulis akan mengusulkan beberapa model yang dirasa pas untuk dimasukkan dalam jajaran ide yang telah muncul puluhan tahun sebelumnya di ranah Teologi Agamaagama. Dengan mempertimbangkan dasar Alkitab dan pengalaman yang ada di ladang pelayanan, model (jalan lain) itu patut dipertimbangkan untuk digunakan demi kedamaian kehidupan masyarakat dalam konteks perbedaan keyakinan.

\footnotetext{
${ }^{16}$ Ginting, "Theologia Religionum (Teologi Agama-Agama)."

${ }^{17}$ Thio Christian Sulistio, “Teologi Agama Dari Persfektif Reformed: Sebuah Sketsa,” VERITAS 15 (2) (2014): 253-270.

${ }^{18}$ Ibid.

${ }^{19}$ Alan Race, Christian and Religious Pluralism: Pattern in the Christian Theology of Religions (Maryknoll, NY: Orbis Books, 1983).

${ }^{20}$ Eriyanto, Analisis Isi: Pengantar Metodologi Untuk Kajian Ilmu Komunikasi Dan Ilmu-Ilmu Sosial Lainnya (Jakarta: Kencana Prenada Media Group, 2011), 32.
} 
Dari beberapa studi sejarah telah menggambarkan kelindan yang terkait erat bahwa masyarakat nusantara (Indonesia) adalah masyarakat agamis yang ketat. Sejak dahulu kala telah memiliki kepercayaan kepada sesembahan tersendiri (agama suku) dan sejak masa Zending para misionar Kristen dan syiar Islam masuk, masyarakat Indonesia menerima kehadirannya meski ada benturan-benturan perjumpaan di beberapa daerah. Mengingat ruang yang terbatas dan atas dasar kalimat sebelumnya, tulisan ini memulai dari kedua agama yakni Kristen dan Islam yang akan menjadi pola untuk memunculkan ide. Meski penulis meyakini temuan dalam tulisan ini bermanfaat bagi semua agama-agama. Dari beberapa studi sejarah telah menggambarkan kelindan yang terkait erat bahwa masyarakat nusantara (Indonesia) adalah masyarakat religious-agamis yang ketat. Sejak dahulu kala telah memiliki kepercayaan kepada sesembahan tersendiri (agama suku) dan sejak masa zending para misionar Kristen dan syiar Islam masuk, masyarakat Indonesia menerima kehadirannya meski ada benturanbenturan perjumpaan di beberapa daerah. Di Indonesia, secara nyata dapat dilihat bahwa agama dalam kaitannya dengan kehidupan sosial masyarakat, politik dan berbangsa. Data dari kitab suci Alkitab didalami dengan pola hermeneutik ${ }^{21}$, dengan memperhatikan konteks kepenulisannya ketika peristiwa dalam perikop Kitab Suci itu berlangsung. Prinsip memperhatikan genre ini dirasa penting untuk menemukan hasil tafsiran yang bertanggung jawab. ${ }^{22}$

\section{Pembahasan}

Teologi Agama-agama pada dasarnya merupakan upaya dari dalam komunitas keagamaan tertentu, khususnya Kristen, untuk melakukan refleksi atau pemikiran yang runtut tentang kesadaran baru sebagai upaya untuk memberi respon terhadap persoalan pluralisme. Teologi Agama-agama tidak lain adalah upaya refleksi teologis untuk menempatkan pluralisme sebagai pusat perhatian dan pusat persoalan. Dan tugas esensial dari agama adalah membuat dirinya relevan dengan keadaan sedangkan teologi agama-agama merupakan respon seseorang terhadap keseluruhan masa depan masyarakat maupun agama-agama yang ada. Masa depan menjadi masa depan bersama. Apalagi jika dilihat dari kebangkitan semangat pemeluk agama di dunia pasca tahun 1970-an dan perkembangan pesat dari dalam agama Kristen sendiri. Dalam teologi agama-agama umat diarahkan pada bagaimana agar tetap menjaga identitas keagamaannya masing-masing tanpa meremehkan pemahaman dan praktik pemeluk agama lain. Sekalipun ada agama yang pengajarannya mirip dengan kekristenan, tidak jadi jaminan terciptanya kerukunan. Misalnya kesamaan dalam nama nabi dan peristiwa-peristiwa tertentu dalam proses penciptaan serta kejatuhan manusia dalam dosa. Karena bagaimanapun, seperti dinyatakan Sulistio, bahwa ada agama yang dekat dengan kekristenan, dan ada yang sangat jauh bertentangan. ${ }^{23}$ Lebih jauh diharapkan pada tahap mampu menghargai identitas keagamaan orang lain dan integritas agama orang lain seturut ajaran yang dipercayainya.

Melihat fakta awal di atas, ditengarai teologi agama-agama bermuara pada dua maksud secara kualitatif yaitu dialog dan kolaborasi antar agama. Dialog yang dimaksud adalah keterbukaan untuk saling memperbincangkan perbedaan tanpa memaksakan keyakinan (teologi)-

${ }^{21}$ Oskar Skarsaune, "Biblical Interpretation," in The Early Christian World, 2017.

${ }^{22}$ Hasahatan Hutahaean, "Pengantar Memahami Surat Roma Dengan Baca Gali Alkitab," CULTIVATION 1 (2017): 217.

${ }^{23}$ Sulistio, "Teologi Agama Dari Persfektif Reformed: Sebuah Sketsa." 
nya kepada orang lain. Kelompok yang bermuara pada bidang ini, oleh Stevri Lumintang ${ }^{24}$ diidentifikasi sebagai kaum Oikumenikal di dalam Kekristenan. Sedangkan yang berkolaborasi adalah penggabungan dua keyakinan berbeda untuk memperoleh keharmonisan dalam kemajemukan. Meski keduanya tampak baik, namun penulis menganggap bahwa keduanya mempunyai kerawanan akan titik jenuh keharmonisan. Hal ini karena masing-masing (dialog dan kolaborasi) mempunyai arah yang berbeda karena itu pada titik tertentu akan saling melepas kebersamaanya.

Teologi Agama-agama bukan dimaksudkan untuk mengatasi perbedaan antar agama, namun, menurut hematnya, untuk memberi makna positif terhadap agama-agama tersebut sehingga perbedaan tersebut benar-benar secara positif diterima sebagai berkah dan anugerah Tuhan. Pertanyaan patut diajukan untuk bisa menerima hal ini, yaitu misalnya; bagaimana reaksi berkomunikasi orang Kristen jika Muhammad SAW misalnya lahir pada tahun 10 SM? Apakah penganut Buddha bahkan masih berargumen jika nirwana tersebut benar-benar di telapak kaki ibu? Bahkan masih adakah perdebatan Yahudi-Kristen-Islam yang (rasanya) tidak akan putus tentang siapakah keturunan Ibrahim (Abraham) sesungguhnya, yang menjadi pewaris iman kepada Allah Yang Esa itu ${ }^{25}$ Pertanyaan-pertanyaan seperti ini jika dirunut lagi akan menuntun masing-masing pemeluk agama terhadap kerukunan dan penghargaan yang besar terhadap perbedaan teologi. Bagi penulis perbedaan-perbedaan ini adalah alat dan bahan istimewa bagi antar umat beragama dalam mewujudkan model teologi agama-agama yang akan melahirkan kehidupan yang rukun dan harmonis.

Untuk hal tersebut patut pula diajukan pertanyaan histori imajiner lanjutan. Misalnya, bagaimana jika 350 tahun penjajahan di Indonesia dilakukan oleh bangsa Arab, dan di dalamnya ada syiar Islam? Apakah pandangan orang Kristen terhadap agama Islam di Indonesia? Belum lagi jika keragaman itu diperhadapkan dengan kebijakan pemerintah untuk mengatur kehidupan beragama, di mana, menurut Daniel, agama dijadikan salah satu penentu identitas kewargaan rakyat Indonesia dalam KTP. ${ }^{26}$ Praktik seperti ini menjadikan keberagaman agama dan puluhan aliran kepercayaan di Indonesia kian kehilangan arah serta tujuan dalam merangkai teologi agama-agama yang harmonis. Selama lima belas tahun terakhir agama menjadi diskursus, di mana nyata terlihat terjadi kompetisi di antara rezim kebenaran yang dibela agama masing-masing yang mungkin tidak berjalan seimbang, dimana terjadi di dalamnya bahwa agama yang satu menguasai agama lainnya.

Padangan terhadap teologi agama-agama dalam ranah Kristen, sangat populer yaitu apa yang disebut oleh Alan Race dengan "tipologi tripolar" yang selama ini masih eksis. Tokoh ini yang masih disebut-sebut untuk diskusi teologi agama-agama dan berikutnya adalah Gavin D'Costa dan Paul F Knitter. ${ }^{27}$ Di Indonesia tidak banyak yang mendobrak eksistensi pandangan ini. Meski demikian di dunia internasional "tipologi tripolar" juga tidak mendapat

\footnotetext{
${ }^{24}$ Stevri L Lumintang, Teologia Abu-Abu Pluralisme Agama (Malang: Gandum Mas, 2004).

${ }^{25}$ Band. Paul F Knitter, Pengantar Teologi Agama-Agama (Yogyakarta: Kanisius, 2014), 2, 4 Pertanyaan cara seperti ini juga ditemui dari Knitter, pada halaman 4 ditulis, "Mengapa keragaman agama yang sudah ada sejak semula ini dialami secara berbeda-beda di berbagai tempat sekarang ini?"

${ }^{26}$ Daniel Lucas Lukito, “Eksklusivisme, Inklusivisme, Pluralisme Dan Dialog Antar-Agama.,” VERITAS 12 (2012): 513.

${ }^{27}$ Harmakaputra, Melepas Bingkai.
} 
respon berarti kepada bentuk perlawanan. Beberapa teolog menerimanya dengan sedikit penambahan dan pengurangan, itupun bukan dalam hal esensi dari defenisinya. Harmakaputra memberi tambahan sedikit dari praksis tipologi tipolar tersebut dengan mendorong dibukanya dialog antar iman yang konkret ${ }^{28}$, dan penuh kerendahan hati tentunya. Eksklusivisme, Inklusivisme dan Pluralisme adalah anak sulung kandung yang lahir kembar dalam konteks ini. Sebab banyak yang menerima serta memujanya namun tak sedikit pula memandangnya sebelah mata, bahkan ada yang menduga tipologi tripolar menjadi biang merosotnya iman di gereja serta dangkalnya pemahaman di jemaat akan keberagaman dan perbedaan teologi agama-agama. Lumintang dalam bukunya menyebut bahwa pluralisme menghancurkan Kekristenan dari dalam gereja; meskipun memakai dan mengaku berdasarkan kitab suci, teologi pluralisme telah mengarah pada sinkritisme dan sekularisme sehingga warnanya tidak jelas (abu-abu). ${ }^{29}$ Di bagian lain disebutkan juga, bahwa subur dan menjamurnya teologi yang tidak jelas itu (abu-abu) turut didukung oleh lembaga pendidikan teologi yang tidak bermutu, munculnya literatur dari pendanaan yang kuat.

Eksklusivisme, singkatnya menyatakan bahwa di luar Yesus Kristus tidak ada keselamatan. Bagi tipologi jenis ini, Kristus final dan satu-satunya jalan untuk setiap orang yang akan dibebaskan dari hukuman selama-lamanya setlah kematiannya. Eksklusivisme, di kelompok ini akan ditemukan mayoritas pada teolog fundamentalis dan injili yang mengklaim bahwa Allah secara unik berkarya di dalam Yesus Kristus semata, dan karena itu, maka agama Kristen adalah satu-satunya agama unik dan benar. Satu-satunya sarana pengetahuan umat untuk mengetahui tentang Allah yang bekerja dalam sejarah dan kehidupan adalah Alkitab. Dengan demikian hanya orang-orang yang secara sadar memiliki hubungan dengan kristus, kepada merekalah dibierikan kemampuan menikmati kehidupan kekal di surga. Dengan demikian dapat dimengerti jika eksklusivisme mengatakan dengan hakin bahwa di luar gereja (kristus) tidak ada keselamatan. Yang uniknya bahwa dalam kelompok ini meyakini bahwa tidak ada kontiniutas dengan agama lainnya. Bagi Samuel B Hakh tipologi jenis ini berpotensi menggiring penganutnya pada tahap fanatisme agama. ${ }^{30}$ Hakh melihat tokoh Kristen Belanda yang pernah melayani di Indonesia masuk dalam jenis ini adalah Hendrik Kraemer. Kemudian Hakh mempertanyakan keabsahan tipologi ini berangkat dari pertanyaan Race, bahwa akankah Allah bisa dikungkung oleh aliran agama tertentu sehingga karyaNya tidak mampu masuk kepada agama-agama lain di luar Kristen. ${ }^{31}$

Inklusivisme berpandangan bahwa di luar Kristus tidak ada keselamatan, namun karena di agama lain ada nilai-nilai yang sama, maka mungkin ada keselamatan di luar agama Kristen. Dalam tatanan interaksi agama-agama, Lukito menggambarkan model ini aktif mengikuti dialog dengan agama lainnya sehingga memperkaya khazanah keimanan Kristen seraya menyerap kebenaran-kebenaran kepercayaan non-kristiani tersebut demi kesempurnaan dan kekayaan nilai kristiani. ${ }^{32}$ Inklusivisme menaruh perhatian terutama terhadap pernyataan me-

\footnotetext{
${ }^{28}$ Ibid.

${ }^{29}$ Lumintang, Teologia Abu-Abu Pluralisme Agama.

${ }^{30}$ Samuel Benyamin Hakh, Merangkai Kehidupan Bersama Yang Pluralis Dan Rukun (Jakarta: BPK Gunung Mulia, 2017), 7-19.

${ }^{31}$ Race, Christian and Religious Pluralism: Pattern in the Christian Theology of Religions.

${ }^{32}$ Lukito, "Eksklusivisme, Inklusivisme, Pluralisme Dan Dialog Antar-Agama."
} 
ngenai partisipasi dalam keselamatan kekal. Mereka mempertahankan keyakinan yang sama seperti ekslusivis bahwa Yesus Kritus satu-satunya anak Allah yang menyediakan jalan keselamatan dan hanya melalui Dia seseorang dapat memperoleh hidup kekal, meskipun kelompok ini juga mengakui bahwa ada kemungkinan keselamatan bagi orang-orang yang tidak memiliki kesempatan mendengar dan merespon Injil. Tokoh di kategori ini misalnya John Sanders dalam bukunya No Other Name; An Investigation into Destiny of the Unevangelized (1992). Kelompok ini dengan sadar menegaskan kekhususan dan finalitas keselamatan hanya pada Yesus Kristus, namun dalam kesadaran juga menyangkal bahwa pengetahuan tentang pekerjaan Yesus semata diperlukan untuk keselamatan. Karena itu pemahaman dalam penganut inklusif ini dapat menerima hadiah keselamatan tanpa mengetahui pemberi atau sifat pemberian yang pasti dari Yesus atau Sang Ilahi Yang lain.

Dalam perkembangan terkini, dari kelompok inkulusivisme misalnya Karl Rahner ${ }^{33}$ memahaminya dalam lingkup yang lebih luas lagi. Kelompok ini beranggapan bahwa di dalam kepercayaan-kepercayaan lain juga disalurkan keselamatan Allah meski tidak ada Yesus. Ini ditandai dengan gemar mengadakan dialog mutual dengan penganut agama lain karena mereka percaya Allah bisa saja bekerja secara simultan melalui agama-agama lain itu. Untuk kelompok ini ada Karl Rahner (1904-1984), teolog Katolik yang dikenal perumus dan pencetus anonymous Christian. Anonymous Christian yang dimaksud adalah orang-orang non-kristen dan agama di luar Kristen juga mempunyai kesempatan untuk diselamatkan. Apabila di dalam diri mereka terpancar nilai-nilai yang juga diajarkan dalam Alkitab. Implikasi dari kebenaran Alkitab yang terpancar itulah menjadi konfirmasi bahwa mereka (individu dan non-Kristen) juga meneladani Kristus, sehingga dengan demikian mereka juga diselamatkan.

Pada bagian ini, beberapa kaum injili masih sulit menerima sebab konsep iman, Kristus, Allah atau keselamatan agama-agama lain karena tentu berbeda dengan Kristen. Juga berbeda dengan teologi agama-agama perikoresis Joas Adiprasetya ${ }^{34}$. Secara praktis, teologi agamaagama pendekatan perikoretik Joas Adiprasetya adalah dengan mendiskusikan perbedaanperbedaan dari doktrin trinitas bersama pemeluk agama lain. Tentu dengan landasan "harus menghargai tradisi-tradisi agama lain seturut pemahaman tradisi agama mereka sendiri." 35 Bagi Joas pembicaraan Trinitas tetap bersandar kepada pemahaman dari kekristenan, dengan berdasar pada dua syarat yakni; "pengakuan terhadap terhadap deskripsi diri agama-agama dan penekanan pada kebebasan umat beragama lain untuk menerima atau menolak undangan Allah untuk keselamatan." 36

Pada prinsip unity of reality Adiprasetya sebagaimana dipaparkan Aritonang ${ }^{37}$, masingmasing agama menyatu dalam realitas atau ilahi serta non-ilahi dalam arti persekutuan. Jika hal ini dimaksudkan untuk memadukan masing-masing pemahaman tiap-tiap agama, maka perbedaan nama agama sekalipun adalah sebuah ironi yang lucu dalam realitas keberagaman. Pluralisme, di luar Allah tidak ada keselamatan. ${ }^{38}$ Di agama lain, yang ber-Allah ada kesela-

\footnotetext{
${ }^{33}$ Knitter, Pengantar Teologi Agama-Agama.

${ }^{34}$ Adiprasetya, An Imaginative Glimpse; Trinitas Dan Agama-Agama.

${ }^{35}$ Ibid. 202

${ }^{36}$ Ibid. 209

${ }^{37}$ Ginting, "Theologia Religionum (Teologi Agama-Agama)."

${ }^{38}$ Knitter, Pengantar Teologi Agama-Agama.
} 
matan. Bahkan bagi kalangan penganut pluralism radikal meyakini, bahwa agama Kristen bukanlah agama yang benar atau bahkan tertinggi nilai kebenarannya dibandingkan agamaagama besar lainnya di dunia. Kelompok highest pluralism percaya bahwa penggenapan hukum-hukum Kristiani ada pada agama-agama non-Kristen. Dengan demikian mereka percaya bahwa semua agama adalah sah dan tidak ada yang dapat dengan jujur mengklaim superioritas supremasi diantara agama lainnya, tak terkecuali agama Kristen.

Dalam pluralisme ilah yang dipercaya tidak lagi fokus kepada Yesus Kristus, tetapi Allah. Kelompok ini meyakini bahwa (layaknya ilmu pengetahuan dan progresivitas dunia), revolusi dalam rangka pergeseran Chirst-mindedness kepada perspektif God-conscious tidak dapat dihindarkan. Harusnya orang-orang Kristen mengakui bahwa iman Kristen juga berevolusi meski di rotasi yang sama (tetap pada Yesus), juga dialami oleh agama lain, yang disebut dengan Allah. Dengan demikian Allah tidak melulu ditemukan di dalam Kristus Yesus. Karena dengan demikian kekuasaan Allah yang mahabesar, terkurung atau terpenjara dalam Yesus, meski Yesus menyatakan diri sebagai Anak Allah. Dengan demikian Kekristenan adalah sebuah optional dalam pilihan menuju keselamatan.

Jauh sebelumnya, sekitar pertengahan abad ke-20 telah muncul gugatan legalitas bahwa hanya di dalam Yesus Kristus dan Gereja terdapat jalan keselamatan. Validitas itu dipertanyakan dalam satu buku yang mengamati kemurnian keagamaan seseorang melalui rasa humanisnya, bukan dari klaim verbal kebenaran tentang wahyu Allah yang didapat dari Alkitab saja. Untuk klaim ini tentu menjadi perbin-cangan yang panjang, serta mendasar bagi Kekristenan. Sekalipun diskusi dalam ini tidak mengarah ke hal tersebut, namun patut untuk diperhatikan pendapat Binsar Hutabarat, bahwa jika demi mewujudkan masyarakat yang rukun, harmonis, tidak elok jika seorang pemeluk Kristen harus melacurkan kebenaran yang dipercayainya sesuai ajaran Alkitab. ${ }^{39}$ Keinginan mewujudkan masyarakat yang rukun, damai dan harmonis berbeda dengan upaya mengabur-kan kebenaran dogmatis satu ajaran agama tertentu. Karena pada agama-agama yang ada di dunia, pada dasarnya tidak ada yang mengajarkan untuk membenci pemeluk agama lain serta menghina atau memandangnya rendah.

Setelah melihat tiga jalan tipologi tripolar yang ada, maka pada bagian selanjutnya akan fokus kepada model lain yang diusulkan dalam tulisan ini untuk menuju suatu teologi agamaagama yang harmonis. Dalam pengalaman empirik melalui berbagai diskusi dengan tokoh Islam misalnya Prof. Katimin (UIN-SU, Medan) dan studi literatur terhadap isu ini, tibalah pada tiga pendekatan (baca: jalan lain) penulis dalam bidang teologi agama-agama. Sebagai bangsa yang kaya akan perbedaan, tentu warga Indonesia tidak boleh salah mempersepsikan keragaman ini. Wiranata menggambarkan keharmonisan dalam keberagaman demikian,

Kehidupan warga negara multikultural diharapkan masyarakat bisa menerima segala bentuk perbedaan dan juga hidup berdampingan secara damai. Masyarakat harus hidup dalam bingkai kebhinekaan yang mengutamakan nilai-nilai kemanusiaan daripada mempertentangkan perbedaan ideologi atau perbedaan keyakinan. Keanekaragaman merupakan suatu khazanah kekayaan Bangsa Indonesia dan merupakan anugerah dari Tuhan Yang Maha Kuasa yang membedakan dan memberi arti kekhasan bangsa Indonesia dengan bangsa lainnya, yang utama sebagai bangsa Indonesia, harus menjaga

${ }^{39}$ Binsar A Hutabarat, "Pluralisme Agama Dan Finalitas Keselamatan: Satu Paradigma Baru," STULOS 11 (2012): 220 . 
kesatuan, persatuan, dan keutuhan, serta harus senantiasa terjaga dalam bingkai kebhinekaan berdasarkan falsafah luhur Pancasila. ${ }^{40}$

Dengan berbagai usulan dan modifikasi yang akan dipaparkan semoga menjadi usulan yang tepat untuk situasi sekarang ini. Adapun jalan lain itu pertama adalah: perjumpaan kreatif.

Pertama diusulkan yaitu perjumpaan yang kreatif. Istilah ini diungkapkan oleh Deonal Sinaga $^{41}$, yang menyatakan perjumpaan kreatif sebagai tindakan menciptakan suatu kondisi yang kreatif sehingga menimbulkan kenyamanan dalam perkenalan dan kemudian pembicaraan. Apapun isi diskusi yang dibangun, karena telah didahului oleh penciptaan suasana yang nyaman, saling menghormati, menerima perbedaan, serius dalam percakapan serta unsur lainnya yang berimplikasi kepada hospitality, sehingga ada ketertarikan untuk menjalin komunikasi selanjutnya meskipun memiliki perbedaan pandangan terhadap satu isu. ${ }^{42}$ Bagaimana pentingnya tesis ini untuk terciptanya teologi agama-agama yang harmonis?

Teologi adalah segmen yang sensitif dalam pembicaraan di antara teolog. Menurut isinya, tentu teologi Kristen dan non-Kristen berbeda. Dalam perspektif teologi agama-agama tentu diskursus teologis acap kali diperhadapkan terhadap perbedaan teologi karena subyeknya, yaitu Theos, yang dibahas juga berbeda. Misalnya dalam literatur Islam, secara terminologi, teologi adalah ilmu yang membahas tentang Tuhan dan segala sesuatu yang terkait dengan-Nya. Istilah yang sering digunakan adalah tauhid, di mana kata tauhid ini mengandung arti satu atau esa dan keesaan; sebuah konsep dalam akidah Islam yang menyatakan keesaan Allah. Topik tauhid sangat penting dalam pembicaraan kaum muslim. ${ }^{43}$ Karena begitu pentingnya, maka orang-orang harus super hati-hati jika memperbincangkan ke-tauhid-an ini dengan orang lain, tidak kecuali sesama muslim. Dalam Kristen, topik ini mempunyai peranan yang besar dalam menentukan sikap keseharian dan cara seseorang dalam mengambil keputusan.

Sehubungan dengan pentingnya memulai percakapan dalam tiap perjumpaan, membuat seseorang akan terdorong dalam menjalin dialog dan komunikasi terhadap orang lain, termasuk yang berbeda agama. Sehingga, bagi seseorang berdialog dengan baik adalah satu hikmat dan harta tersendiri dalam dirinya yang berguna untuk menjalin dan menciptakan kehidupan beragama yang harmonis. Salomo mengutarakan pentingnya percakapan atau dialog yang baik, dengan menulis, "perkataan yang diucapkan tepat pada waktunya adalah seperti buah apel emas di pinggan perak" (Ams. 25:11). Josua Choonmin Kang, juga memberi penjelasan, "pendeta dan rohaniwan pembimbing dan pengarah rohani, harus sanggup mengadakan pecakapan terhormat dengan seseorang yang membutuhkan atau meminta pertolongan." 44 Lebih lanjut Kang menjelaskan perihal yang perlu diperhatikan untuk mewujudkan dari perkataan

\footnotetext{
${ }^{40}$ Marzuki Wiranata, Irawan Hadi, “Kerukunan Antar Umat Beragama Sebagai Dasar City Branding Harmoni Kediri The Service City," Ilmiah Pendidikan Pancasila dan Kewarganegaraan 3 (1) (2018): 65.

${ }^{41}$ Deonal Sinaga, "Perjumpaan Kreatif," in Prosiding Sejarah Dan Pertumbuhan Gereja, ed. Gundari Ginting (Medan: Prodi Teologi STT-SU, 2016), 2-12.

${ }^{42}$ Ibid.

${ }^{43}$ Agus Miswanto, Agama, Keyakinan, Dan Etika (Magelang: Pusat Pembinaan dan Pengembangan Studi Islam Universitas Muhammadiyah, 2012), 49.

${ }^{44}$ Joshua Choonming Kang, Alkitab Dalam Hati (Jakarta: Yayasan Indonesia Cahaya Rahmat Empati, 2020), 92 .
} 
yang diucapkan dengan tepat. Pertama, bahwa bahasa itu berkuasa. ${ }^{45}$ Kedua, dalam menciptakan percakapan yang kreatif harus tunduk kepada golden rule yang dikenal dari Matius 7:12. Ketiga, dalam percakapan pernting untuk menjaga karakter diri agar tidak terjebak dalam kepura-puraan. Keempat, mempertimbangkan waktu dan durasi dari percakapan. Dan kelima, menjaga kearifan dan keenam, meningkatkan hubungan yang lebih tinggi sampai pada pertukaran intelektual dan bahkan hingga pertukaran emosional.

Karena demikian sensitifnya segmen ini, maka tidak ada cara yang lebih baik kecuali memulainya dengan perjumpaan yang kreatif. Untuk masuk dalam pembicaraan kreatif, memang seseorang memerlukan sikap open minded. Perjumpaan kreatif membutuhkan karakter orang-orang yang sedemikian: "integritas, kerendahan hati, keramahtamahan, keterbukaan, berpikir posi-tif, gemar bertanya, compassionate, pendamai, keadilan dan visioner"46, agar tercipta dialog dengan baik. Dengan mencari momentum untuk menciptakan dialog guna "mengatasi keadaan bermusuhan dan menciptakan modus vivendi yang damai dan kooperatif." "47 Suatu terobosan istilah telah dimulai oleh seorang bernama Lailatuz Zuhriyah seorang mahasiswa di IAIN Tulungagung. Teologi konvergensi menjadi alternatif untuk menciptakan kerukunan hidup umat beragama, yaitu dengan menerima bahwa dalam belief seseorang berbeda, namun dalam faith beberapa orang bisa mempunyai kesamaan. ${ }^{48}$ Dalam penjelasan berikutnya Zuhriyah mengharapkan ada kreativitas dari seseorang untuk menciptakan pembicaraan yang pengarah kepada kenyamanan meski mempunyai perbedaan faith. Karena dalam faith mempercayai adanya Allah yang Esa, namun dalam belief mempercayai bahwa Allah yang Esa itu adalah satu oknum yang dikenal dengan sebutan berbeda dari masing-masing pemeluknya. Kemudian Zuhriyah menerangkan bahwa yang dimaksud teologi konvergensi adalah upaya untuk memahami agama dengan melihat intisari persamaan atau titik temu dari masing-masing agama agar dapat diintegrasikan. Dalam perkembangannya, convergence theology disebut juga dengan istilah teologi global yang mengusahakan pertemu-an bersama atara berbagai agama di dunia. Sehingga dapat juga disebut dengan teologi universal. ${ }^{49}$

Dalam hal inilah ada sedikit kesamaan konsep antara perjumpaan kreatif dengan konsep yang ditawarkan oleh Zuhriyah. Namun pada akhirnya yang membedakan dengan Sinaga adalah pada tujuan akhir dari teologi konvergensi. Tujuan utama dari teologi ini ialah ingin menyatukan unsur-unsur esensial dalam agama-agama sehingga tidak tampak lagi perbedaan prinsipil yang kerap menjadi penghalang bertemu dan bersatunya berbagai agama dengan harmoni. Dengan demikian, pemeluk berbagai agama yang berbeda dapat dipersatukan dalam konsepsi teologi yang universal yang disepakati dan umatnya dapat dipersatukan dalam satu umat beragama. Sedangkan perjumpaan kreatif menciptakan hubungan yang nyaman, tenang, bersahabat dan saling membutuhkan meski ada perbedaan, baik dalam faith maupun belief.

${ }^{45}$ Kang, Alkitab Dalam Hati.

${ }^{46}$ Hasahatan Hutahaean, "Perjumpaan Kreatif Bagi Pertumbuhan Gereja Batak," Didaskein IV No.1 (2016): 68 .

${ }^{47}$ Mariani Harmadi, "Metafora 'Meja Makan' Sebagai Upaya Membangun Toleransi Di Tengah Kehidupan Masyarakat Indonesia Yang Majemuk,” Dunamis 4 (1) (2019): 105.

${ }^{48}$ Lailatuz Zuhriyah, "Teologi Konvergensi Dan Kerukunan Umat Beragama," Religió: Jurnal Studi Agama-agama IV (2014): 78-95.

${ }^{49}$ Zuhriyah, "Teologi Konvergensi Dan Kerukunan Umat Beragama." 
Adapun model atau jalan lain kedua menuju teologi yang harmonis adalah dengan memaparkan dan mempertahankan. Memaparkan apa yang menjadi iman percayanya kepada penganut agama lain dengan benar tanpa mengarahkan kesalahan kepada lawan bicara dalam pembicaraan. Sekaligus mampu mempertahankan diskusi dalam ranah kebenaran tanpa mengarah kepada kebiasaan yang salah dari pemeluk agama lain atau mempersoalkan kepribadiannya (ad hominem). Model ini dipahami dari buku Jhon Frame Apologetika Bagi Kemuliaan Allah (2000), yang memberikan beberapa arahan dalam mempertahankan iman percaya. Di antaranya adalah agar seseorang dalam berapologetika memiliki kepercayaan dan pengetahuan iman Kristen yang menyeluruh secara benar. Frame juga mengingatkan agar orang Kristen tidak asal tuduh serta koreksi budaya dengan pengetahuan yang tidak komprehensif. Stenly Paparang memaparkan tiga tujuan berapologetika, di mana satu di antaranya terkait tujuan klarifikasi ${ }^{50}$, agar tidak salah mendudukkan kebenaran sejati dalam rangka pemberitaan Injil.

Berangkat dari pemahaman tersebut, maka jalan lain kedua dalam tulisan ini yang diajukan yaitu pemahaman teologi yang menyeluruh. Dengan meminjam istilah "disrupsi” yang beberapa kali dipakai oleh Renald Kasali, maka dapat disebutkan dengan disrupsi teologi. Disrupsi dalam artian perubahan yang menyeluruh, lebih mendasar atau fundamental. Dengan pengertian bahwa teologi harus menyeluruh kembali kepada tujuan awalnya, mempercakapkan Allah untuk memahaminya dalam banyak hal. Dengan defenisi baru dari sudut hakikatnya, teologi adalah segala sumber daya yang dapat dimaknai untuk berbicara, mempercakapkan Tuhan, sehingga seseorang memahami yang dibicarakan/percakapkan dan menjadi pemancar isi hati Tuhan dalam pelbagai kesempatan. Dengan berteologi yang benar dan bertanggung jawab maka banyak orang dengan sendirinya menemukan Tuhan yang terpancar dari diri seseorang.

Model ketiga menuju teologi yang harmonis yaitu percakapan-percakapan teologi yang baik (disrupsi teologis) bertujuan kepada perubahan pemahaman tentang Allah menuju kembalinya iman yang sesungguhnya serta pemahaman yang komprehensif. Pemahaman komprehensif dalam hal ini berangkat dari pemahaman Alkitab yang baik seturut makna yang terkandung di dalamnya berdasar olah tafsir yang benar. Sehingga percakapan teologi itu dibangun dan berdasar dari arti dan makna Alkitab. Maksudnya, dalam menuju kembalinya iman adalah dengan mendasarkan teologi, pemahaman bidang-bidang teologi dengan baik karena meyakini pemahaman yang baik akan menghasilkan bentuk praktik ibadah dan hidup yang benar kepada Allah yang benar. Keyakinan penulis adalah pemahaman Allah yang benar menuntun kepada perilaku keseharian yang benar dan damai sejahtera, tak terkecuali dalam hidup berdampingan bersama masyarakat yang berbeda agama. Sehingga dalam berinteraksi tentang iman atau kepercayaan lain orang Kristen tidak salah kaprah. Orang Kristen tidak menjurus kepada tujuan sempit untuk mengkristenkan belaka. Poin ini berangkat dari keyakinan bahwa iman, pemahaman kepada Allah yang benar berdasarkan penuturan Alkitab secara murni (pure), memberi tuntunan yang baik dan benar untuk memasuki keragaman teologi di masyarakat yang majemuk sekarang ini, bahkan kian beragam. Tentu hal ini diperoleh dari pemaha-

\footnotetext{
${ }^{50}$ Stenly R Paparang, Apologetika Diskursus Dan Vindikasi Iman Kristen, ed. Hasahatan Hutahaean (Medan: Prodi Teologi STT-SU, 2016), 24.
} 
man Alkitab yang benar ${ }^{51}$, sebagai bagian kedewasaan dalam beriman pada Yesus. Kisah Yesus bertemu dengan perempuan Samaria di Alkitab seperti tertulis di Injil Yohanes pasal 4 (Yoh.4) membantu untuk memahami hal ini.

Yesus sengaja mengambil jalur ke Galilea via Samaria daripada mengitari rute itu dari Yerusalem, sehabis bertemu Nikodemus. Nikodemus sendiri memframing pembaca ayat Yohanes 4:1-42, bahwa sekelas guru besar ternyata memiliki pemahaman yang tidak lengkap tentang keselamatan. Bukan hanya itu Nikodemus juga memiliki konsepsi misi yang salah dengan dasar pengertian miring terhadap orang Samaria. Samaria adalah keturunan Yahudi yang telah bercampur dengan suku di Utara, dan memiliki sesembahan lain selain Yahweh. Bait Allah bagi orang Samaria penuh kesalahan, kekeliruan termasuk Bait di Yerusalem telah penuh kekeliruan. Sejak masa pembuangan Israel ke Babel, pemisahan spiritualitas orang Israel di utara dan Selatan (yang kemudian kembali ke Yerusalem) tampak jelas berbeda. Karena itu, pembicaraan Yesus dengan perempuan Samaria (Yoh. 4) sarat dengan perbaikan ajaran iman yang salah bagi Samaria maupun kalangan Yudaisme. Bahwa Bait Allah perlu benar dan suci benar adanya, bahwa orang Samaria berdosa juga benar adanya, namun bagi Yesus yang terpenting kala itu (dan seterusnya bagi kita masa kini) adalah agar seseorang "menyembah Allah dalam roh dan kebenaran," (Yoh. 4:24).

Tentang kisah ini, Ida Glaser memaparkan

Orang Yahudi berpikir bahwa orang Samaria memiliki bait yang keliru. Yohanes telah memperlihatkan salam 2:13-24 bahwa bait Yerusalem cemar adanya. Dalam percakapan dengan perempuan Samaria, Yesus mengakui dalam arti tertentu orang yahudi benar, sebab Allah telah memilih mereka untuk membawa keselamatan. Namun dalam arti lain mereka salah: pada akhirnya, tak satu pun bait tersebut yang penting, tetapi "penyembahan dalam roh dan dalam kebenran" (4:24). Pertanyaan tentang praktik religious adalah tidak benar. Yang diperlukan adalah suatu pendekatan yang sepenuhnya beda-kelahiran baru. ${ }^{52}$

Dari perspektif interpretasi teologis ${ }^{53}$, Yesus mau berterus terang tentang posisiNya sebagai Juru selamat melalui percakapan di lokasi sumur Yakub dengan perempuan Samaria. Karena kata "air hidup" (hudor zaw) pembukaan percakapan teologis ini jadi titik poin percakapan selanjutnya untuk pemaparan pemahaman yang benar akan Juru selamat. Secara khusus bagi kalangan Kristen Injili, hal ini menjadi dorongan untuk terus berupaya memberitakan Injil melalui percakapan-percakapan teologis yang baik dan benar. Karena, sekalipun Allah telah memilih nan menentukan orang-orang pilihanNya, tetapi Allah tetap memakai manusia untuk memberitakan Injil. ${ }^{54}$ Dari isu bahasan dalam tulisan ini, memberitakan Injil kepada banyak orang dapat dilakukan dengan cara tersebut.

\footnotetext{
${ }^{51}$ Linda Zenita Simanjuntak, “Kedewasaan Rohani Dan Pertumbuhan Gereja,” Asteros 2 (2015): 40.

${ }^{52}$ Glasaer, Alkitab Dan Kepercayaan Lain.

${ }^{53}$ Hendry Ongkowidjojo, “Theological Interpretation Of Scripture; Suatu Pengantar,” Amanat Agung 9 (1) (2013): 45 .

${ }^{54}$ Timotius Cong, "Kontroversi The Well-Meant Offer of the Gospel Dalam Konsep Penginjilan John Calvin," Reformed Indonesia 7 (2) (2017): 110. Band: Fransiskus Irwan Widjaja, Daniel Ginting, and Sabar Manahan Hutagalung, "Teologi Misi Sebagai Teologi Amanat Agung," THRONOS: Jurnal Teologi Kristen 1, no. 1 (2019): 17-24.
} 
Pada poin ini tidak bisa diragukan lagi bahwa pemahaman dasar-dasar iman Kristen dan praksisnya yang benar serta murni menurut pengajaran Alkitab harus diciptakan, dan harus dimiliki, agar benturan dalam konteks keberagaman teologi dihindari. Tentunya dengan mengajukan hipotesis, bahwa jika seseorang memiliki pemahaman teologi yang baik dan benar berdasarkan Alkitab, maka yang bersangkutan akan mampu merangkai teologi agamaagama secara damai, harmo-nis dan menggairahkan (bahkan). Sebab, demikian menurut Paparang, bahwa "relasi kita dengan sesama manusia menjadikan identitas kita bernilai dan membangun orang lain-memberi pengaruh positif dalam setiap komunitas dimanapun kita berada." 55 Tentu semangat ini agar mewujudkan hubungan yang harmoni di tengah masyarakat yang berbeda-beda suku, agama dan keyakinan. Penulis berkeyakinan atas tiga usulan itu untuk menambah cara menjadikan gereja "berpikir dan bertindak secara strategi" 56 dalam mewujudkan Amanat Agung Yesus.

\section{Kesimpulan}

Keberagaman adalah keindahan jika bisa ditata dengan baik dan benar. Ibarat satu rangkaian bunga, akan indah jika disusun berdasarkan bererapa warna dan bentuk bunga, dengan tatanan yang benar. Pemaksaan keserupaan warna tentu tidak seindah perpaduan dari beberapa warna. Tulisan ini menekankan agar tidak terjadi pemaksaan teologi, baik dalam lingkup antaragama maupun antar dogmatika gereja, sehingga keharmonisan dapat terwujud di antara perbedaan. Deklarasi Umum Hak azasi manusia (DUHAM), pada pasal 18 dan didukung selanjutnya oleh pasal 19 dan 20, dapat menjadi satu pijakan yang sejurus dengan tulisan ini, yang menyatakan bahwa setiap orang memiliki hak atas kebebasan pikiran, hati nurani dan agama, yang dalam hal ini termasuk kebebasan berganti agama atau kepercayaan, dengan kebebasan menyatakan agama atau kepercayaan dengan cara mengajarkannya, melakukannya (pasal 18). Sedangkan kebebasan untuk bercerita tentang teologi (pendapat) di depan umum dan secara pribadi diakomodir oleh pasal 19. Dengan demikian tidak ada saling paksa atas dasar perintah agama untuk dan dengan dalih pindah agama.

\section{Referensi}

Adiprasetya, Joas. An Imaginative Glimpse; Trinitas Dan Agama-Agama. Jakarta: BPK Gunung Mulia, 2018.

Budijanto, Bambang. "Spiritualitas Generasi Muda Dan Gereja.” In Dinamika Spiritualitas Generasi Muda Kristen Indonesia, edited by Budijanto, 21-58. Jakarta: Bilangan Research Center, 2018.

Cong, Timotius. "Kontroversi The Well-Meant Offer of the Gospel Dalam Konsep Penginjilan John Calvin.” Reformed Indonesia 7 (2) (2017): 93-111.

Drane, John. Memahami Perjanjian Lama III. Edited by Barnabas Ludji. Ketiga. Jakarta: Scripture Union Indonesia, 2017.

Eriyanto. Analisis Isi: Pengantar Metodologi Untuk Kajian Ilmu Komunikasi Dan Ilmu-Ilmu Sosial Lainnya. Jakarta: Kencana Prenada Media Group, 2011.

\footnotetext{
${ }^{55}$ Stenly R Paparang, "Identitas Kristen:Sebuah Pemahaman Relasi Dan Konatif Berdasarkan Aplikasi Biblika," Asteros 3 (2016): 8.

${ }^{56}$ Junihot M. Simanjuntak, "Belajar Sebagai Identitas Dan Tugas Gereja Learning as Church Identity and Duty," Jaffray 16 (1) (2018): 2.
} 
Ginting, Edi S. “Theologia Religionum (Teologi Agama-Agama).” In Teologi-Teologi Kontemporer, edited by Jan S Aritonang, 184-201. Jakarta: BPK Gunung Mulia, 2018.

Glasaer, Ida. Alkitab Dan Kepercayaan Lain. Edited by Paul S. Hidayat. Jakarta: Waskita Publishing, 2012.

Hakh, Samuel Benyamin. Merangkai Kehidupan Bersama Yang Pluralis Dan Rukun. Jakarta: BPK Gunung Mulia, 2017.

Harmadi, Mariani. “Metafora 'Meja Makan' Sebagai Upaya Membangun Toleransi Di Tengah Kehidupan Masyarakat Indonesia Yang Majemuk.” Dunamis 4 (1) (2019): 99110.

Harmakaputra, Hans Abdiel. Melepas Bingkai. Jakarta: Grafika Kreasindo, 2014.

Hutabarat, Binsar A. "Pluralisme Agama Dan Finalitas Keselamatan: Satu Paradigma Baru." STULOS 11 (2012): 221-238.

Hutahaean, Hasahatan. "Pengantar Memahami Surat Roma Dengan Baca Gali Alkitab." CULTIVATION 1 (2017): 216-230.

. "Perjumpaan Kreatif Bagi Pertumbuhan Gereja Batak." Didaskein IV No.1 (2016): 64-73.

Kang, Joshua Choonming. Alkitab Dalam Hati. Jakarta: Yayasan Indonesia Cahaya Rahmat Empati, 2020.

Karkkainen, Veli-Mati. Tritunggal Dan Pluralisme Agama. Jakarta: BPK Gunung Mulia, 2013.

Knitter, Paul F. Pengantar Teologi Agama-Agama. Yogyakarta: Kanisius, 2014.

Lukito, Daniel Lucas. "Eksklusivisme, Inklusivisme, Pluralisme Dan Dialog Antar-Agama." VERITAS 12 (2012): 251-279.

Lumintang, Stevri L. Teologia Abu-Abu Pluralisme Agama. Malang: Gandum Mas, 2004.

Miswanto, Agus. Agama, Keyakinan, Dan Etika. Magelang: Pusat Pembinaan dan Pengembangan Studi Islam Universitas Muhammadiyah, 2012.

Ongkowidjojo, Hendry. "Theological Interpretation Of Scripture; Suatu Pengantar." Amanat Agung 9 (1) (2013): 35-56.

Paparang, Stenly R. Apologetika Diskursus Dan Vindikasi Iman Kristen. Edited by Hasahatan Hutahaean. Medan: Prodi Teologi STT-SU, 2016.

_. "Identitas Kristen:Sebuah Pemahaman Relasi Dan Konatif Berdasarkan Aplikasi Biblika." Asteros 3 (2016): 1-10.

Race, Alan. Christian and Religious Pluralism: Pattern in the Christian Theology of Religions. Maryknoll, NY: Orbis Books, 1983.

Rantung, Djoys Anneke. Resolusi Konflik Dalam Organisasi. Jakarta: BPK Gunung Mulia, 2017.

Sibarani, Theodorus B. "Berteologi Dalam Pembangunan Sosial Di Indonesia." In Dari Disabilitas Ke Penebusan: Potret Pemikiran Teolog-Teolog Muda Indonesia, edited by Samuel Septino Saragih, 167-188. Jakarta: Asosiasi Teolog Indonesia dan BPK Gunung Mulia, 2016.

Simanjuntak, Junihot M. "Belajar Sebagai Identitas Dan Tugas Gereja Learning as Church Identity and Duty." Jaffray 16 (1) (2018): 1-24.

Simanjuntak, Linda Zenita. "Kedewasaan Rohani Dan Pertumbuhan Gereja." Asteros 2 (2015): 38-57.

Sinaga, Deonal. "Perjumpaan Kreatif." In Prosiding Sejarah Dan Pertumbuhan Gereja, edited by Gundari Ginting, 2-12. Medan: Prodi Teologi STT-SU, 2016.

Skarsaune, Oskar. "Biblical Interpretation." In The Early Christian World, 2017.

Sucipto, Hery. Islam Madzhab Tengah. Jakarta: Grafindo Khazanah Ilmu, 2007.

Sulistio, Thio Christian. "Teologi Agama Dari Persfektif Reformed: Sebuah Sketsa." VERITAS 15 (2) (2014): 253-270. 
Tanzil, Vincent. "Dalam Allah Trinitas Dialog Antar Iman Hidup, Bergerak, Dan Ada." Amanat Agung 9 (2) (2013): 221-242.

Widjaja, Fransiskus Irwan, Daniel Ginting, and Sabar Manahan Hutagalung. "Teologi Misi Sebagai Teologi Amanat Agung." THRONOS: Jurnal Teologi Kristen 1, no. 1 (2019): $17-24$.

Wiranata, Irawan Hadi, Marzuki. "Kerukunan Antar Umat Beragama Sebagai Dasar City Branding Harmoni Kediri The Service City." Ilmiah Pendidikan Pancasila dan Kewarganegaraan 3 (1) (2018): 64-73.

Zuhriyah, Lailatuz. "Teologi Konvergensi Dan Kerukunan Umat Beragama.” Religió: Jurnal Studi Agama-agama IV (2014): 1-125. 